\title{
Article \\ Antimicrobial Profile of Actinomycin D Analogs Secreted by Egyptian Desert Streptomyces sp. DH7
}

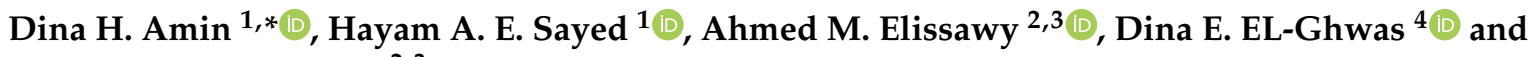 \\ Abdel Nasser B. Singab ${ }^{2,3}$ \\ 1 Department of Microbiology, Faculty of Science, Ain Shams University, Cairo 11566, Egypt; \\ hayam84@sci.asu.edu.eg \\ 2 Department of Pharmacognosy, Faculty of Pharmacy, Ain Shams University, Cairo 11566, Egypt; \\ aelissawy@pharma.asu.edu.eg (A.M.E.); dean@pharma.asu.edu.eg (A.N.B.S.) \\ 3 Center of Drug Discovery Research and Development, Faculty of Pharmacy, Ain Shams University, \\ Cairo 11566, Egypt \\ 4 Pharmaceutical Industries Researches Division, Department of Chemistry of Natural and Microbial Products, \\ National Research Centre, Giza 12622, Egypt; dinaelghwas7781@yahoo.com \\ * Correspondence: dina.hatem@sci.asu.edu.eg
}

check for updates

Citation: Amin, D.H.; Sayed, H.A.E.; Elissawy, A.M.; EL-Ghwas, D.E.; Singab, A.N.B. Antimicrobial Profile of Actinomycin D Analogs Secreted by Egyptian Desert Streptomyces sp. DH7. Antibiotics 2021, 10, 1264. https://doi.org/10.3390/ antibiotics 10101264

Academic Editors: Junying Ma, Linghong Meng and Ling Liu

Received: 5 August 2021

Accepted: 23 September 2021

Published: 18 October 2021

Publisher's Note: MDPI stays neutral with regard to jurisdictional claims in published maps and institutional affiliations.

Copyright: (C) 2021 by the authors. Licensee MDPI, Basel, Switzerland. This article is an open access article distributed under the terms and conditions of the Creative Commons Attribution (CC BY) license (https:// creativecommons.org/licenses/by/ $4.0 /)$.
Abstract: Egyptian deserts are an underexplored ecological niche, especially the Sinai Peninsula. In our recent study, we explored this extreme environment and shed light on the bioactive capabilities of desert Actinobacteria isolated from Sinai. Fifty desert Actinobacteria were isolated from the Sinai desert using mineral salt media, basal media, and starch casein media. The filtrate of Streptomyces sp. DH 7 displayed a high inhibitory effect against multidrug-resistant Staphylococcus aureus (MRSA) strains. The $16 \mathrm{~S}$ rDNA sequencing confirmed that isolate DH7 belongs to the genus Streptomyces. The NJ phylogenetic tree showed relatedness to the Streptomyces flavofuscus strain NRRL B-2594 and Streptomyces pratensis strain ch24. The minimum inhibitory concentrations against MRSA were 16 and $32 \mu \mathrm{g} / \mu \mathrm{L}$. Chemical investigation of the ethyl acetate extract of Streptomyces sp. DH7 led to the isolation and purification of natural products 1-4. Structure elucidation of the purified compounds was performed using detailed spectroscopic analysis including 1 and 2D NMR, and ESI-MS spectrometry. To the best of our knowledge, this is the first report for the isolation of compounds 1-4 from a natural source, while synthetic analogs were previously reported in the literature. Compounds 3-4 were identified as actinomycin D analogues and this is the first report for the production of actinomycin D analogs from the Sinai desert with an inhibitory effect against MRSA. We indorse further study for this analog that can develop enhanced antimicrobial activities. We confirm that the desert ecosystems in Egypt are rich sources of antibiotic-producing Actinobacteria.

Keywords: desert actinobacteria; MRSA; actinomycin D; Sinai desert; Egypt

\section{Introduction}

Multidrug-resistant pathogens are a life-threatening problem that has affected the healthcare domain over the last few decades. There is a consensus that the data collection processes need to be improved, particularly in Africa [1]. Antimicrobial resistance is related to an increase in morbidity, mortality, hospitalization time, and costs of treatment $[2,3]$. Multidrug-resistant Staphylococcus aureus (MRSA) is among the top antimicrobial resistances responsible for many antibiotic-resistant infections worldwide [1,4]. Staphylococcus aureus causes various skin and soft tissue infections, pneumonia, meningitis, bacteremia, osteomyelitis, endocarditis, toxic shock syndrome, and sepsis [5-8]. Multidrug-resistant Staphylococcus aureus has become overwhelmingly popular in Egyptian health care sectors against several antibiotics $[9,10]$. Over the years, the treatment of suspected $S$. aureus infection has been complicated due to the resistance to multiple drug classes. Exploring novel antibiotics that would combat earlier infection has become vital. 
Actinobacteria are among the promising sources of alternative antibiotics [11-13]. Streptomyces is the largest genus of Actinobacteria that belongs to the family Streptomycetaceae [14]. These gram-positive bacteria are saprotrophic in soil and water. Streptomycetes are a rich source of active secondary metabolites such as clinically useful antibiotics of natural origin $[11,15]$. The approach of screening less exploited Actinobacteria in extreme environments is valuable for the discovery of new chemical entities [16]. The 16S rRNA gene sequence and phylogenetic tree analysis are useful methods for the specific identification of Actinobacteria on the genus level and show the differences between the newly identified isolates and other related strains $[17,18]$.

Desert habitats are one of the extremophilic ecosystems that harbor biologically active Actinobacteria strains. They are viewed as an ecosystem equivalent to that of the planet Mars [19]. They contain various unexplored Actinobacteria that withstand abnormal chemical conditions including $\mathrm{pH}$, salinity, and water quality, and physical conditions including temperature, pressure, and radiations. Egyptian deserts are old sources of undiscovered extremophile and extremotroph Actinobacteria strains [20]. The extremophiles grow and flourish at extreme scopes of these physicochemical parameters. In contrast, extremotrophs can grow and tolerate only extreme conditions [21]. The desert of Sinai occupies about $6 \%$ of Egypt and is part of the Sahara-Arab desert. It is viewed as one of the low humidity areas with high mountains and occasional snowfalls in extreme natural environments. The extreme habitat of the Sinai desert varies from other places in Egypt, suggesting that the population of Actinobacteria is likely to vary, alongside, therefore, their biological abilities [22,23].

In this manuscript, we report the power of screening unusual habitats to find new natural products that attack multidrug-resistant $S$. aureus pathogens.

\section{Results}

\subsection{Isolation of Desert Actinobacteria Isolates}

Fifty Actinobacteria were isolated from five soil samples at different parts of the Sinai desert in Egypt. Actinobacteria colonies' growth was detected on mineral salt media, basal media, and starch casein media at $30^{\circ} \mathrm{C}$ only. No colonies were observed at $37^{\circ} \mathrm{C}$ and $45^{\circ} \mathrm{C}$ on the previously stated media types. Starch casein media was the most effective as $50 \%$ of Actinobacteria isolates were recovered on it.

\subsection{Antimicrobial Potential of Desert Actinobacteria Isolates}

Sixteen desert Actinobacteria (32\% of total isolates) were found to inhibit one or more of the pathogenic multidrug-resistant S. aureus isolates, while $34(68 \%)$ showed no antimicrobial activities on the starch casein broth medium. Antimicrobial activities varied against the tested S. aureus isolates and only four isolates ( $8 \%$ ) showed an inhibitory effect against Staphylococcus aureus ATCC 6538. Fourteen isolates (82\%) were inhibitive against multidrugresistant Staphylococcus aureus clinical strains from the Egyptian Hospital. Regarding the specific behavior of the crude extract of isolate DH7 on S. aureus cells, it significantly affected cells' viability of $S$. aureus isolates (No. 35, 37, 39, and 43). The inhibition zone diameters of DH7 crude extract and CN10 antibiotic were $30 \mathrm{~mm}$ and $20 \mathrm{~mm}$ against S. aureus isolates (No. 31) and (55), respectively. The AZM15 antibiotic showed inhibition zone diameters of $26 \mathrm{~mm}$ and $28 \mathrm{~mm}$ against S. aureus isolates (No. 31) and (No. 55), respectively (Table 1). Our findings confirmed that desert Actinobacteria showed significant antimicrobial effects against pathogenic multidrug-resistant S. aureus. Among them, DH7 reported the highest spectrum of antimicrobial activities against all the tested pathogens. Our preliminary results recorded the marked antimicrobial activities of the DH7 isolate against S. aureus ATCC 6538 and against nine multidrug-resistant S. aureus isolates. 
Table 1. The antimicrobial potential of Actinobacteria isolates against multidrug-resistant S. aureus strains.

\begin{tabular}{|c|c|c|c|c|c|c|c|c|c|c|}
\hline \multicolumn{11}{|c|}{ The Diameter of Inhibition Zones in $\mathrm{mm}$ against Multidrug-Resistant $S$. aureus Strains } \\
\hline Tested Isolate & ATCC & No. 30 & No. 31 & No. 34 & No. 35 & No. 37 & No. 39 & No. 43 & No. 55 & No. 60 \\
\hline DH1 & 4 & - & - & - & 10 & - & 4 & - & - & 4 \\
\hline $\mathrm{DH} 2$ & 4 & - & - & - & - & - & - & - & - & - \\
\hline DH3 & 18 & - & - & - & - & - & - & - & - & - \\
\hline DH4 & - & - & - & - & - & - & - & 12 & - & - \\
\hline DH5 & - & 12 & - & - & - & - & - & - & - & - \\
\hline DH6 & - & - & - & - & - & - & - & - & - & - \\
\hline DH7 & 15 & 4 & 4 & 6 & 4 & 22 & 22 & 6 & 18 & 22 \\
\hline DH8 & - & - & 10 & 8 & 4 & 10 & - & 10 & 8 & 8 \\
\hline DH9 & - & 6 & 4 & 6 & - & 2 & 4 & - & - & 4 \\
\hline DH10 & - & - & - & - & - & - & 10 & - & - & - \\
\hline DH11 & - & - & - & - & - & - & - & - & - & 12 \\
\hline DH12 & - & 12 & 12 & 8 & 16 & 10 & 10 & - & - & - \\
\hline DH13 & - & - & - & - & - & - & - & - & - & - \\
\hline DH14 & - & - & - & - & - & 14 & - & - & 6 & - \\
\hline DH15 & - & - & - & - & - & - & - & - & - & - \\
\hline DH16 & - & - & - & - & - & - & - & - & - & - \\
\hline DH17 & - & - & - & - & - & - & - & - & - & - \\
\hline DH18 & - & 12 & 10 & 14 & 10 & 10 & 10 & 16 & 6 & 10 \\
\hline DH19 & - & - & - & - & - & - & - & - & - & - \\
\hline $\mathrm{DH} 20$ & - & - & - & 4 & - & - & - & - & - & 4 \\
\hline DH21 & - & 20 & 20 & 2 & - & - & - & 2 & - & - \\
\hline DH22 & - & - & - & 2 & - & - & 2 & 6 & - & - \\
\hline $\mathrm{DH} 23$ & - & - & - & - & - & - & - & - & - & - \\
\hline DH24 & - & - & - & - & - & - & - & - & - & - \\
\hline DH25 & - & - & - & - & - & - & - & - & - & - \\
\hline DH26-DH50 & - & - & - & - & - & - & - & - & - & - \\
\hline Crude extract DH7 & - & - & 30 & - & 32 & 24 & 24 & 24 & 20 & - \\
\hline Gentamicin (CN10) & - & - & 30 & - & - & - & - & - & 20 & - \\
\hline Azithromycin (AZM15) & - & - & 26 & - & - & - & - & - & 28 & - \\
\hline
\end{tabular}

(-): no inhibition is recorded.

\subsection{Morphological Characterization}

The cultivation of isolate DH7 on starch casein media for 7 days at $30{ }^{\circ} \mathrm{C}$ showed a gray powdery texture, a yellow substrate mycelium, and a yellow exopigment. Microscopic examination using scanning electron microscopy showed the long spore chains of isolate DH7. Spores were globose in shape with a smooth surface (Figure 1).


Figure 1. Microscopic examination of isolate DH7 using electron microscopy. Isolate DH7 was cultivated on starch casein media for 7 days at $30{ }^{\circ} \mathrm{C}$. Aerial, substrate mycelium, and spores were examined using a scanning electron microscope: $(\mathbf{A})$ magnification of the spore chain $(\times 5000)$ and (B) magnification of the spores $(\times 14,000)$. 


\subsection{S rRNA Genes Sequence Analysis and Phylogenetic Tree Construction}

Amplicons of 500-bp segments of the 16S rRNA gene were effectively amplified from partial 16S rRNA genes of DH7. Purified 500-bp fragments of the 16S rRNA gene were sequenced and the partial 16S rRNA gene sequence was submitted to Gen-bank with the accession number (MN153036).

The 16S rRNA gene sequence of isolate DH7 was compared to the nucleotide sequences of Streptomyces strains in the NCBI GenBank database. The comparison showed that Streptomyces fulvissimus strain DSM 40,593 was the closest match to isolate DH7 with blast identity (99\%). Phylogenetic analysis showed one main clade in which isolate DH7 was amongst other Streptomyces strains in the same clade. Similar 16S rRNA gene sequence belonging to Streptomyces flavofuscus strain NRRL B-2594 and Streptomyces pratensis strain ch24 were found to fall under the same category with bootstrap (86\%, Figure 2). Based on previous investigations, we confirmed that strain DH7 isolated from Egyptian soil was identified as belonging to the genus Streptomyces in the family Streptomycetaceae and was also identified as Streptomyces sp. DH7.

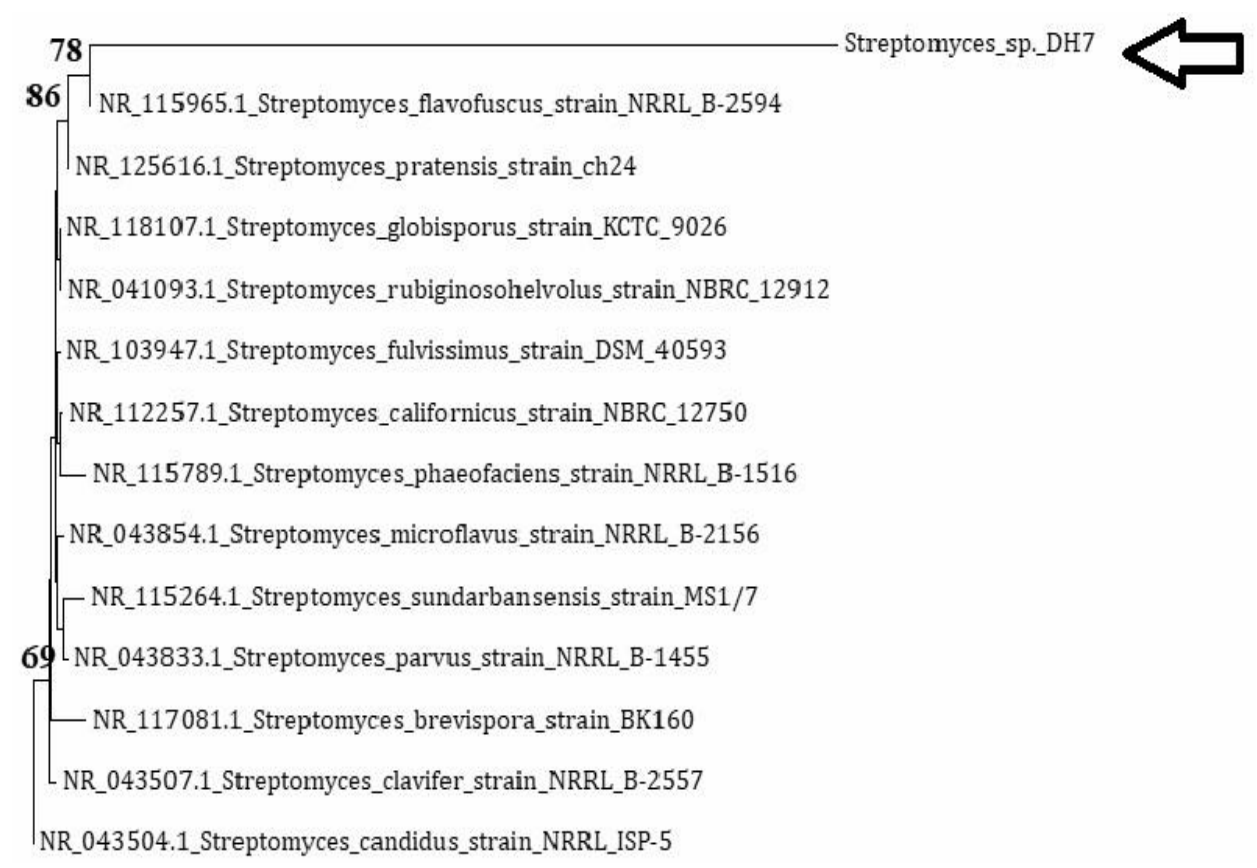

Figure 2. NJ-phylogenetic tree based on partial 16S rRNA gene sequences of Streptomyces sp. DH7 and other Streptomyces species. Phylogenetic analysis was conducted using the CLUSTAL W program and the neighbor-joining phylogenetic tree was constructed using Molecular Evolutionary Genetics Analysis (MEGA) software version 6.

\subsection{Evaluation of the Antimicrobial Activity of the Active Fraction of Streptomyces sp. DH7}

The MIC and the MBC of the active fraction (intermediate compound during purification stages) performed using the micro broth dilution method were similar. Our data emphasized that the active fraction produced by Streptomyces sp. DH7 was highly inhibitive. S. aureus ATCC 6538 was susceptible to the active fraction with MIC of $16 \mu \mathrm{g} / \mu \mathrm{L}$. A gradual inhibition occurred at $0.5,1,2,4$, and $8 \mu \mathrm{g} / \mu \mathrm{L}$, followed by a sharp decline, indicating robust inhibition at the concentration of $16 \mu \mathrm{g} / \mu \mathrm{L}$. Complete inhibition of S. aureus ATCC 6538 was recorded at concentrations of 32, 64, 128, and $256 \mu \mathrm{g} / \mu \mathrm{L}$ (Figure 3). Results were confirmed by the failure of S. aureus ATCC 6538 to grow on nutrient agar plates of $32,64,128$, and $256 \mu \mathrm{g} / \mu \mathrm{L}$, indicating a lack of viability. The previous procedures also confirmed that the minimum bactericidal concentration was $32 \mu \mathrm{g} / \mu \mathrm{L}$, as it was the lowest broth dilution of the active fraction that prevented S. aureus ATCC 6538 growth on the agar plate. Four compounds could be isolated from the active fraction. Only compounds 3 and 4 showed a high inhibitory effect against MRSA strains with a 30 and $50 \mathrm{~mm}$ diameter 
of the inhibition zone, respectively (Figures 4 and 5). We concluded that the biological compound produced by Streptomyces sp. DH7 isolated from the Egyptian Sinai desert is extremely active against multidrug-resistant $S$. aureus. This is the first study to target clinical multidrug-resistant $S$. aureus using the extracts of desert Actinobacteria isolated from the Sinai desert in Egypt.

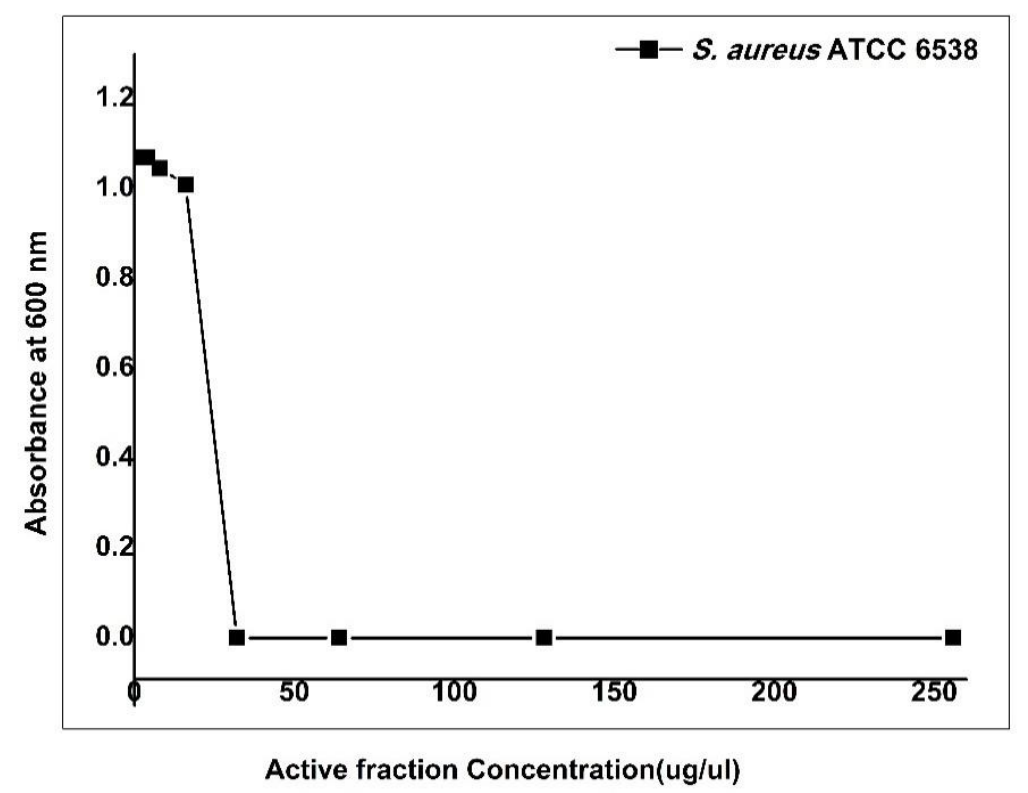

Figure 3. The minimum inhibitory concentration (MIC) of the active fraction of Streptomyces sp. DH7 was tested against $S$. aureus ATCC 6538. A stock solution of the active fraction dissolved in an equal amount of DMSO was used to prepare different concentrations, namely $0.5,1,2,4,8,16$, $32,64,128$, and $256 \mu \mathrm{g} / \mu \mathrm{L}$. An aliquot of $5 \mu \mathrm{L}$ from an overnight culture of S. aureus ATCC 6538 (0.5 Mcfarland) was added to each well of sterile 96-well flat-bottomed microtiter plates containing the test concentrations of the active fraction. Then, optical densities were recorded using a multidetection microplate reader (Bio-Tek-Synergy HT Microplate Reader, BioTek Instruments, Winooski, VT, USA) at $600 \mathrm{~nm}$.

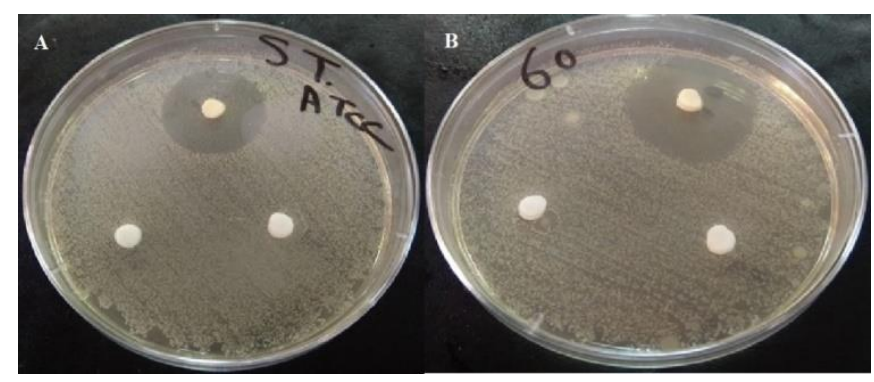

Figure 4. The inhibitive activity of compound 3 isolated from Streptomyces sp. DH7 against (A) S. aureus ATCC 6538 and (B) multidrug-resistant S. aureus No. 60 via the agar disc-diffusion method. Petri dishes were then incubated for $24 \mathrm{~h}$ at $37^{\circ} \mathrm{C}$ and then the inhibition zone areas were recorded. All tests were performed in duplicates. 




Figure 5. The inhibitive activity of compound 4 isolated from Streptomyces sp. DH7 against multidrugresistant S. aureus No. 35 and S. aureus ATCC 6538 via the agar well diffusion method. Petri dishes were then incubated for $24 \mathrm{~h}$ at $37^{\circ} \mathrm{C}$ and then the inhibition zone areas were recorded. All tests were performed in duplicates.

\subsection{Structural Determination of the Compounds Isolated from the Active Fraction}

Four compounds were isolated from the active fraction of Streptomyces sp. DH7. Compound 1 (Figure 6) was isolated as an off-white powder and an APT spectrum of 1 revealed the presence of six carbon signals classified as one methyl, two methylenes, one methine, and two quaternary carbons. Careful inspection of the chemical shift $\left(\delta_{C}\right)$ values confirmed the presence of ketone and amide groups at $\delta_{C} 205$ and $172 \mathrm{ppm}$, which were assigned as $\mathrm{C}-2$ and $\mathrm{C}-1^{\prime}$, respectively. The ${ }^{1} \mathrm{H}$ NMR spectrum showed the presence of a de-shielded methyl group at $\delta_{\mathrm{H}} 2.01 \mathrm{ppm}$, assigned as the acetamide group, as well as four diasterotopic methylene protons, assigned as $\mathrm{H}-3$ and $\mathrm{H}-4$ at $\delta_{\mathrm{H}} 3.44$ and 3.29 for $\mathrm{H}-3 \mathrm{~A}$ and $\mathrm{H}-3 \mathrm{~B}$, in addition to $\delta_{\mathrm{H}} 2.59$ and 2.15 for $\mathrm{H}-4 \mathrm{~A}$ and $\mathrm{H} 4 \mathrm{~B}$. COSY correlations (Figure 7) confirmed the $\mathrm{H}-\mathrm{H}$ connectivity with strong correlations between $\mathrm{H}-1$ at $\delta_{\mathrm{H}} 4.66$ and $\mathrm{H}-4 \mathrm{~A}$ and $\mathrm{B}$, whereas the latter showed correlations with $\mathrm{H}-3 \mathrm{~A}$ and $3 \mathrm{~B}$. Long-range $\mathrm{HMBC}$ correlations (Figure 7) showed $J_{3}$ and $J_{2}$ correlations that confirmed the precise positioning of the functional groups with the Methyl protons at $\delta_{\mathrm{H}} 2.01$, which showed only one correlation with the amide carbon $\mathrm{C}-1^{\prime}$, confirming its assignment as a terminal acetamide methyl group. Moreover, $\mathrm{H}-1$ at $\delta_{\mathrm{H}} 4.66$ showed two $J_{3}$ correlations with amide carbon and $\mathrm{C}-3$, and one $J_{2}$ correlation with ketone carbon, the latter showing one $J_{3}$ correlation with $\mathrm{H}-4 \mathrm{~A}$ and $\mathrm{B}$ as well as one $J_{2}$ correlation with $\mathrm{H}-3 \mathrm{~A}$ and $\mathrm{B}$, confirming the presence of a cyclobutanone ring. Compound 2 (Figure 6) was isolated as an off-white amorphous powder. The 1D and 2D NMR spectra of 2 revealed a similar pattern to compound 1, with the disappearance of the terminal acetamide methyl group and the presence of the ethyl group instead, as evidenced by the presence of additional methylene groups at $\delta_{\mathrm{H}} 2.27$, showing COSY correlation (Figure 7) with an upfield methyl group at $\delta_{\mathrm{H}} 1.16$; both protons $\left(\mathrm{H}-2^{\prime}\right.$ and $\left.\mathrm{H}-3^{\prime}\right)$, in turn, showed strong HMBC correlations (Figure 7) with the amide group C-1' at $\delta_{C} 176.1 \mathrm{ppm}$ (Table 2, Figures S1-S10).

Compound 3 (Figure 6) was isolated as a reddish powder and LC-ESI-MS showed pseudo-molecular ion peaks at $m / z 1270$ and 636, corresponding to $[\mathrm{M}+\mathrm{H}]^{+}$and $[\mathrm{M} \backslash 2+\mathrm{H}]^{2+}$, respectively, where multiply charged ion peaks are common characteristics in peptide mass spectra. The APT-NMR spectrum of compound 3 showed 63 distinct carbon peaks classified as sixteen methyls, fifteen methines, nine methylenes, and twentythree quaternary carbons. Among the carbon signals, 12 distinct amide/ester carbons were present in the range $\delta_{C} 166-173 \mathrm{ppm}$. Additionally, one carbon at $\delta_{C} 179 \mathrm{ppm}$ marked the presence of exocyclic conjugated ketone carbon. Moreover, 11 aromatic carbons were distinct in the range $\delta_{C} 101-147 \mathrm{ppm}$, including two ortho-coupled protonated carbons at $\delta_{C} 125.8$ and $130.3 \mathrm{ppm}$. Two aromatic methyls were evident at $\delta_{C} 7.4$ and $15.1 \mathrm{ppm}$. The values of the carbon chemical shifts together with the long-range HMBC correlations indicated the presence of hexazinone moiety with the conjugated exocyclic ketone at $\delta_{\mathrm{C}}$ 179 ppm (Table 3). 



1, $\mathrm{R}=\mathrm{CH} 3$

2, $\mathrm{R}=\mathrm{CH} 2 \mathrm{CH} 3$

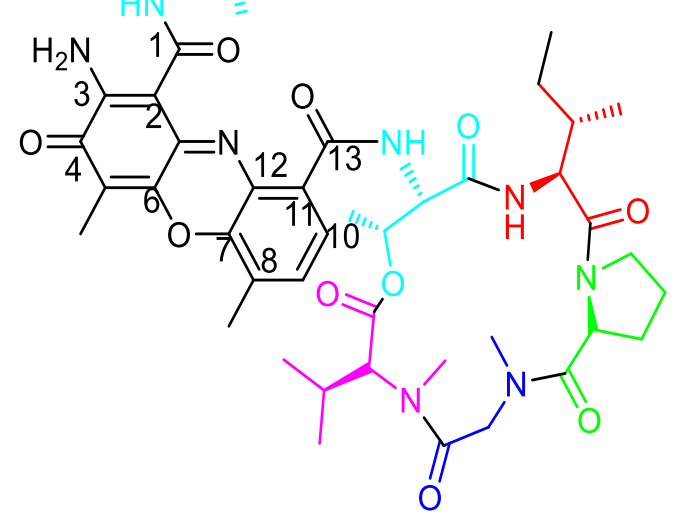

3, $\mathrm{R}=\mathrm{H}$

$4, \mathrm{R}=\mathrm{CH} 3$

Figure 6. Chemical structures of compounds 1-4.

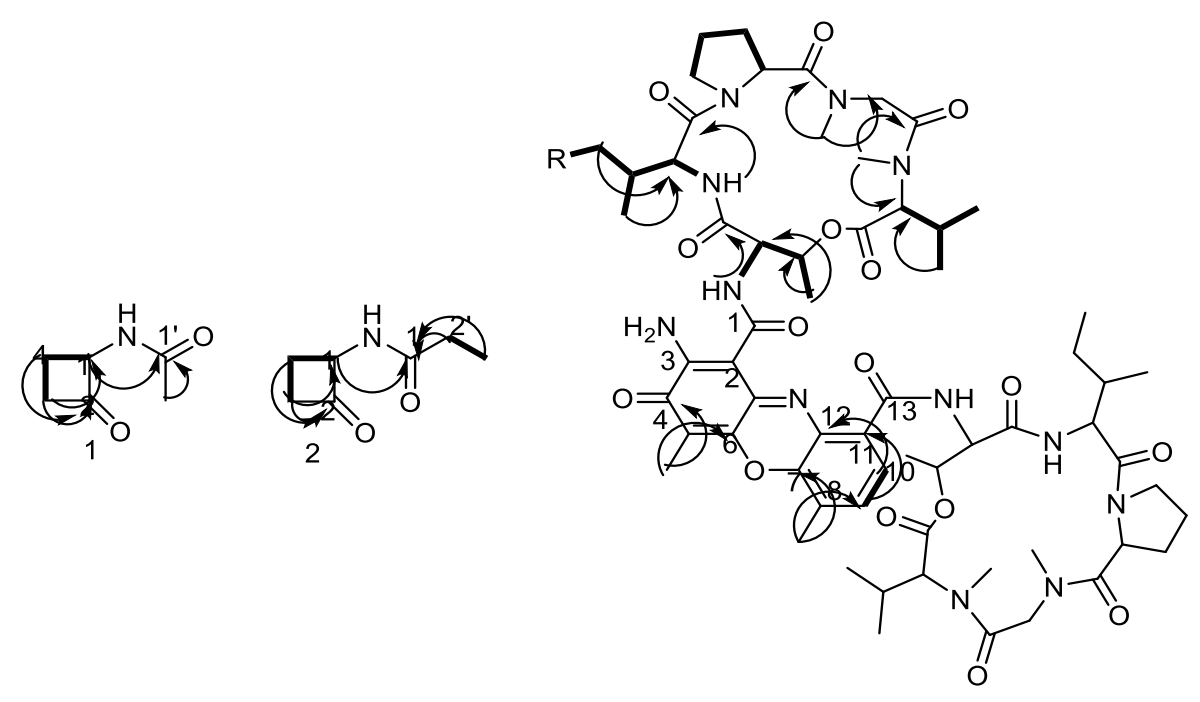

- COSY- correlations

Figure 7. COSY and HMBC correlations of compounds 1-4. 
Table 2. One dimension NMR data of compounds $\mathbf{1}$ and 2.

\begin{tabular}{ccccc}
\hline No. of (C-Atoms) & \multicolumn{2}{c}{ Compound 1 } & \multicolumn{2}{c}{ Compound 2 } \\
\hline$\#$ & $\delta_{\mathrm{H}}^{*}$ & $\delta_{\mathrm{C}}^{*}$ & $\delta_{\mathrm{H}}^{*}$ & $\delta_{\mathrm{C}}^{*}$ \\
1 & $4.66(\mathrm{dd}, 7,12)$ & $58.3 \mathrm{CH}$ & $4.65(\mathrm{dd}, 7,12)$ & $58.5 \mathrm{CH}$ \\
2 & - & $205.4 \mathrm{C}$ & - & 205.7 \\
3 & $3.44(\mathrm{~m})$ & $27 \mathrm{CH} 2$ & $3.43(\mathrm{~m})$ & $26.6 \mathrm{CH} 2$ \\
& $3.29(\mathrm{~m})$ & & $3.29(\mathrm{~m})$ & \\
4 & $2.59(\mathrm{~m})$ & $30.2 \mathrm{CH} 2$ & $2.58(\mathrm{~m})$ & $30.7 \mathrm{CH} 2$ \\
$1^{\prime}$ & $2.15(\mathrm{~m})$ & $172.2 \mathrm{C}$ & $2.14(\mathrm{~m})$ & $176.1 \mathrm{C}$ \\
$2^{\prime}$ & - & - & $28.6 \mathrm{CH} 2$ \\
$3^{\prime}$ & $2.01(\mathrm{~s})$ & $21.2 \mathrm{CH} 3$ & $2.27(q, 7.6)$ & $9 \mathrm{CH} 3$ \\
& $*$ & - & $1.16(t, 7.6)$ & \\
\hline
\end{tabular}

In addition, the proton NMR revealed typical patterns of the amino acid residues with four distinct doublet $\mathrm{NH}$ amide protons at $\delta_{\mathrm{H}} 7.18,7.75,8.02$, and $8.17 \mathrm{ppm}$, together with four $N$-Me groups at $\delta_{\mathrm{H}} 2.89,2.90,2.92$, and $2.96 \mathrm{ppm}$. Additionally, two distinct de-shielded protons at $\delta_{\mathrm{H}} 6.01$ and $6.03 \mathrm{ppm}$ presented on two upfield carbons at $\delta_{\mathrm{C}} 56.34$ and $56.42 \mathrm{ppm}$, marking the presence of two proline residues. The ${ }^{1} \mathrm{H}$ and ${ }^{13} \mathrm{C}$ NMR chemical shifts marking proline residues were matched with the reported chemical shifts of the cis conformers [24]. In adding the information from the amide protons, amide methyls, amide/ester carbons, and the cis-proline methine protons, we determined the presence of ten amino acid residues with eight amide connections and two ester connections between threonine and valine residues. The additional two amide bonds linked the peptide chains with the phenoxazinone residue through the threonine residue. The proton and APT spectral pattern indicated the duplication of the amino acid residues, i.e., the presence of two sets of five amino acids distributed in two distinct chains.

Long-range HMBC (Figure 7) correlations confirmed the connections of the amino acid residues with key HMBC correlations between $\mathrm{N}$-Me groups and both glycine and $\mathrm{N}$-Methyl valine residues, together with $\mathrm{HMBC}$ correlations between aromatic methyl protons at $\delta_{\mathrm{H}} 2.27$ as well as at $\delta_{\mathrm{C}} 179,113$, and $145 \mathrm{ppm}$, marking its position between an exocyclic conjugated ketone and oxygenated aromatic carbon. Similarly, the other aromatic methyl protons at $\delta_{\mathrm{H}} 2.57$ showed correlations with $\delta_{\mathrm{C}} 140.8$ and 129.5, and with the protonated aromatic methine at $130.3 \mathrm{ppm}$. Additionally, COSY (Figure 7) and TOCSY correlations confirmed the presence of isoleucine moiety with distinct correlations between $\delta_{\mathrm{H}} 1.46(\mathrm{CH} 2$ at $\delta \mathrm{c} 25.04)$ and triplet methyl at $\delta_{\mathrm{H}} 0.91$ COSY. TOCSY correlations confirmed the proton spin system of each amino acid residue, including the protonated amide protons. Compound 4 (Figure 6) was isolated as a reddish powder and LC-ESI-MS (Figure 8) showed pseudo-molecular ion peaks at $\mathrm{m} / \mathrm{z} 1284$ and 642, corresponding to $[\mathrm{M}+\mathrm{H}]^{+}$and $[\mathrm{M} \backslash 2+\mathrm{H}]^{2+}$, respectively. The 1D and 2D NMR data of compound 4 showed a similar pattern to compound 3 as shown in Table 4 and Figures S11-S22. 


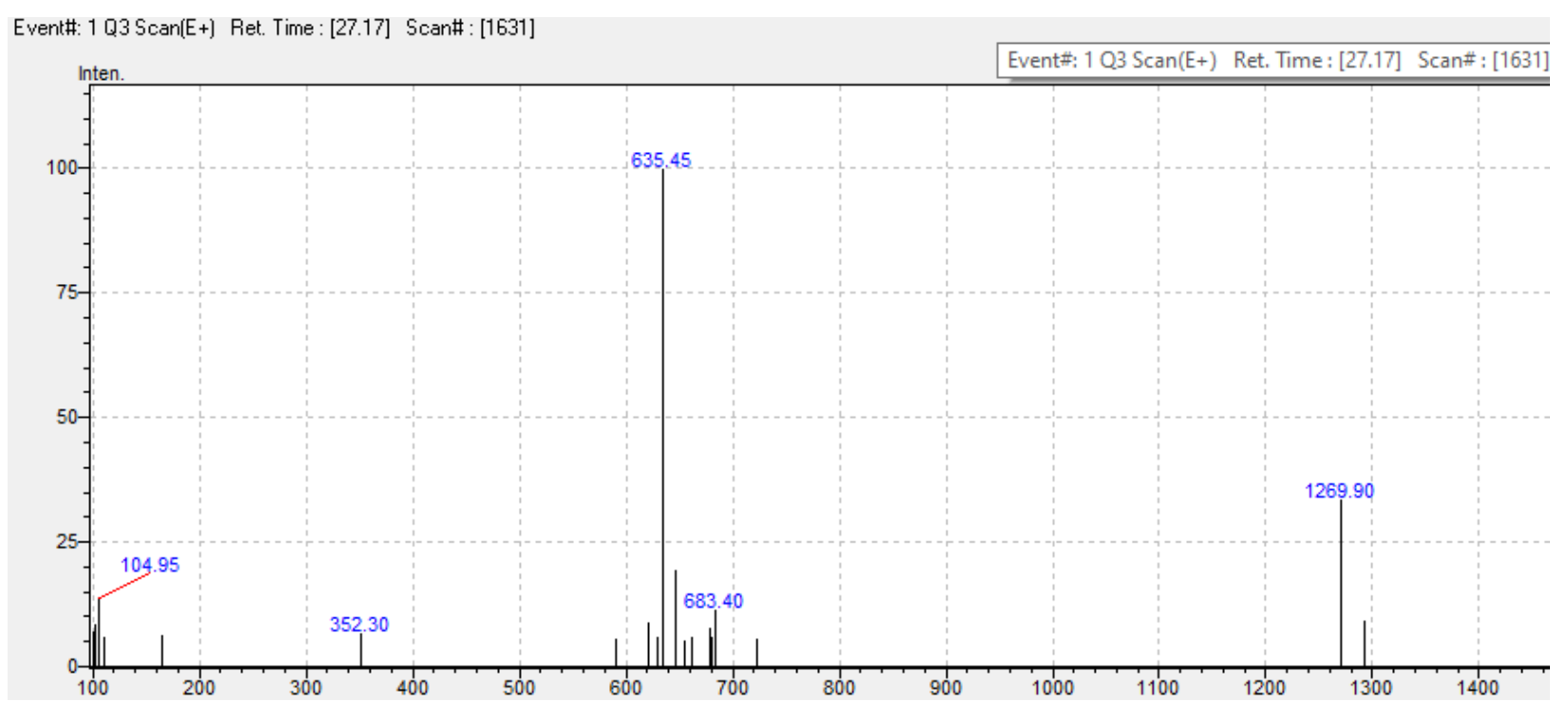

(A)

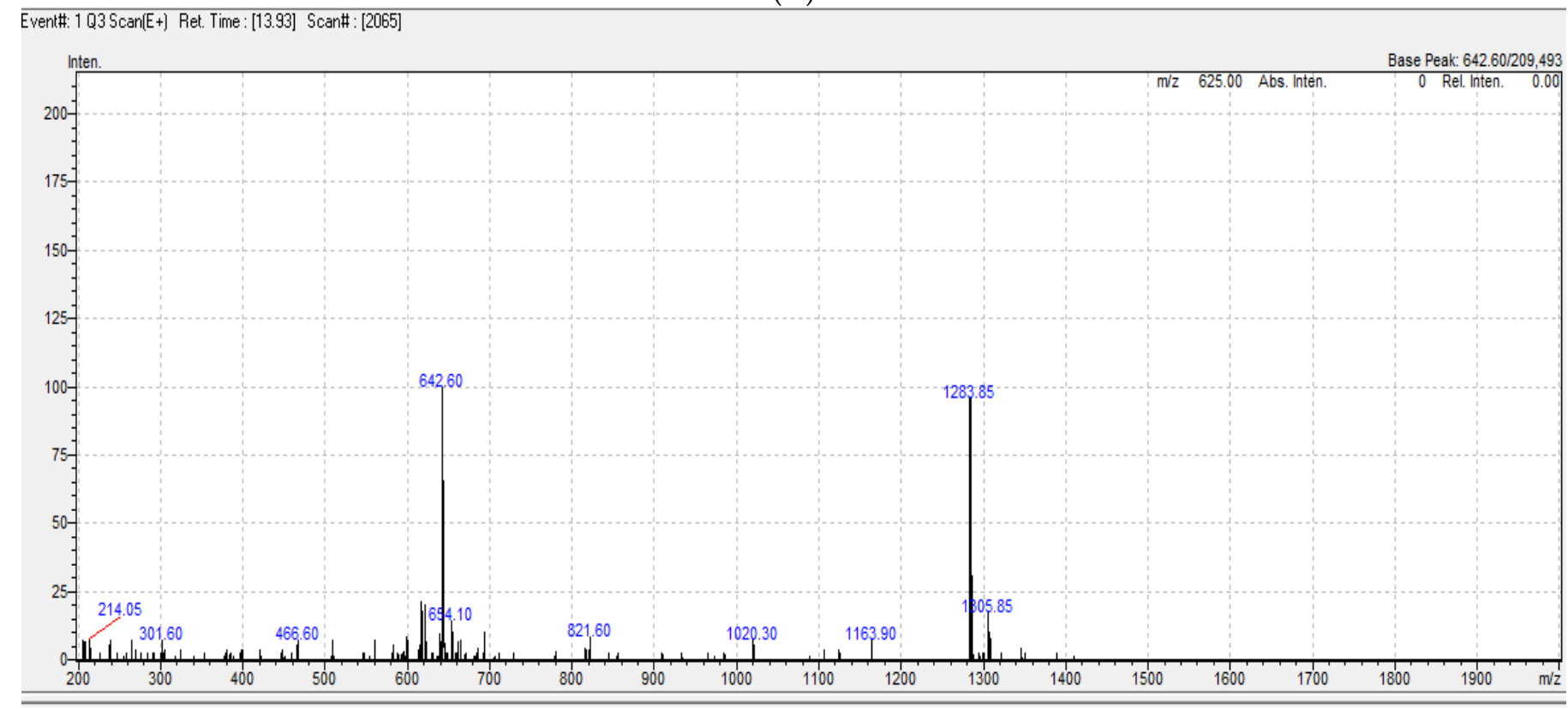

(B)

Figure 8. ESI-MS data of compound 3 (A) and 4 (B).

Table 3. One dimension NMR data of compound 3.

\begin{tabular}{|c|c|c|c|c|c|}
\hline Residue * & $\begin{array}{c}\delta_{\mathrm{H}}\left(\mathrm{CDCl}_{3}, 400\right. \\
\mathrm{MHz}, \text { and } J \text { in } \mathrm{Hz})\end{array}$ & $\begin{array}{c}\delta_{\mathrm{C}}\left(\mathrm{CDCl}_{3} \text { and }\right. \\
100 \mathrm{MHz})\end{array}$ & Residue & $\begin{array}{c}\delta_{\mathrm{H}}\left(\mathrm{CD}_{3} \mathrm{OD}, 400\right. \\
\mathrm{MHz}, \text { and } J \text { in } \mathrm{Hz})\end{array}$ & $\begin{array}{c}\delta_{\mathrm{C}}\left(\mathrm{CDCl}_{3} \text { and }\right. \\
100 \mathrm{MHz})\end{array}$ \\
\hline \multirow{6}{*}{ Thr } & Ring A & & \multirow{6}{*}{ Thr } & Ring B & \\
\hline & $7.75 \mathrm{NH}(\mathrm{d}, 6.5)$ & - & & $7.18 \mathrm{NH}(\mathrm{d}, 6.8)$ & - \\
\hline & $4.62(\mathrm{dd}, 2.3,6.5)$ & $54.9 \mathrm{CH}$ & & $4.54(\mathrm{dd}, 2.3,6.8)$ & $55.2 \mathrm{CH}$ \\
\hline & $5.22(\mathrm{~m})$ & $75.1 \mathrm{CH}$ & & $5.22(\mathrm{~m})$ & $75.1 \mathrm{CH}$ \\
\hline & $1.27(\mathrm{~m})$ & $17.5 \mathrm{CH} 3$ & & $1.29(\mathrm{~m})$ & $17.4 \mathrm{CH} 3$ \\
\hline & - & 168.5 & & - & 167.5 \\
\hline \multirow[t]{6}{*}{$N$-Me Val } & $2.92(\mathrm{~s})$ & $39.2 \mathrm{~N}-\mathrm{Me}$ & \multirow[t]{6}{*}{$N$-Me Val } & $2.96(N-\mathrm{Me})$ & $39.3 \mathrm{~N}-\mathrm{Me}$ \\
\hline & $2.7(\mathrm{~m})$ & $71.2 \mathrm{CH}$ & & $2.8(\mathrm{~m})$ & $71.4 \mathrm{CH}$ \\
\hline & $2.69(\mathrm{~m})$ & $26.9 \mathrm{CH}$ & & $2.68(\mathrm{~m})$ & $26.9 \mathrm{CH}$ \\
\hline & $0.75(\mathrm{~m})$ & $19.07 \mathrm{CH} 3$ & & $0.76(\mathrm{~m})$ & $19.13 \mathrm{CH} 3$ \\
\hline & $0.98(\mathrm{~m})$ & $21.6 \mathrm{CH} 3$ & & $0.99(\mathrm{~m})$ & $21.7 \mathrm{CH} 3$ \\
\hline & - & $167.7 \mathrm{C}$ & & & $166.5 \mathrm{C}$ \\
\hline
\end{tabular}


Table 3. Cont

\begin{tabular}{|c|c|c|c|c|c|}
\hline Residue * & $\begin{array}{c}\delta_{\mathrm{H}}\left(\mathrm{CDCl}_{3}, 400\right. \\
\mathrm{MHz} \text {, and } J \text { in } \mathrm{Hz})\end{array}$ & $\begin{array}{c}\delta_{\mathrm{C}}\left(\mathrm{CDCl}_{3} \text { and }\right. \\
100 \mathrm{MHz})\end{array}$ & Residue & $\begin{array}{c}\delta_{\mathrm{H}}\left(\mathrm{CD}_{3} \mathrm{OD}, 400\right. \\
\mathrm{MHz}, \text { and } J \text { in } \mathrm{Hz})\end{array}$ & $\begin{array}{c}\delta_{\mathrm{C}}\left(\mathrm{CDCl}_{3} \text { and }\right. \\
100 \mathrm{MHz})\end{array}$ \\
\hline \multirow[t]{3}{*}{ N-Me Gly } & $2.9(\mathrm{~s})$ & $34.8(N-\mathrm{Me})$ & N-Me Gly & $2.91(\mathrm{~s})$ & 34.9 (N-Me) \\
\hline & $4.78,3.63(\mathrm{~m})$ & $51.4 \mathrm{CH} 2$ & & $4.77,3.65$ & $51.4 \mathrm{CH} 2$ \\
\hline & & $166.5 \mathrm{C}$ & & & $167.5 \mathrm{C}$ \\
\hline \multirow[t]{5}{*}{ Pro } & $6(d, 9.25)$ & $56.4 \mathrm{CH}$ & Pro & $6.03(\mathrm{~d}, 9.3)$ & $56.2 \mathrm{CH}$ \\
\hline & $2.11,2.30(\mathrm{~m})$ & $22.8 \mathrm{CH} 2$ & & $2.13,2.32$ & $23.0 \mathrm{CH} 2$ \\
\hline & $3.75,3.98(\mathrm{~m})$ & $47.3 \mathrm{CH} 2$ & & $3.75,3.86$ & $47.6 \mathrm{CH} 2$ \\
\hline & $1.85,2.71(\mathrm{~m})$ & $31.0 \mathrm{CH} 2$ & & $1.87,2.95$ & $31.2 \mathrm{CH} 2$ \\
\hline & & $173.2 \mathrm{C}$ & & & $173.3 \mathrm{C}$ \\
\hline \multirow[t]{7}{*}{ D-Val } & $8.17 \mathrm{NH}(\mathrm{d}, 6)$ & - & Isoleu & $8.01 \mathrm{NH}(\mathrm{d}, 6.2)$ & - \\
\hline & $3.57(\mathrm{~m})$ & $58.9 \mathrm{CH}$ & & 3.62 & $58.6 \mathrm{CH}$ \\
\hline & 2.24 & $31.6 \mathrm{CH}$ & & 1.91 & $38.6 \mathrm{CH}$ \\
\hline & $1.15(\mathrm{~d}, 6.6)$ & $19 \mathrm{CH} 3$ & & $1.46,0.96$ & $25.01 \mathrm{CH} 2$ \\
\hline & 0.92 & $19.3 \mathrm{CH} 3$ & & $1.11(\mathrm{~d}, 6.6)$ & $14.9 \mathrm{CH} 3$ \\
\hline & & & & $0.91 \mathrm{~m}$ & $12.5 \mathrm{CH} 3$ \\
\hline & - & $173.2 \mathrm{C}$ & & - & $173.7 \mathrm{C}$ \\
\hline \multicolumn{6}{|l|}{ Phenoxazinone } \\
\hline 1 & & \multicolumn{4}{|c|}{$168.8 \mathrm{C}$} \\
\hline 2 & & \multicolumn{4}{|c|}{$101.8 \mathrm{C}$} \\
\hline 3 & & \multicolumn{4}{|c|}{$147.5 \mathrm{C}$} \\
\hline 4 & & \multicolumn{4}{|c|}{$179.1 \mathrm{C}$} \\
\hline 5 & & \multicolumn{4}{|c|}{$113.5 \mathrm{C}$} \\
\hline 6 & & \multicolumn{4}{|c|}{$145.2 \mathrm{C}$} \\
\hline 7 & & \multicolumn{4}{|c|}{$140.5 \mathrm{C}$} \\
\hline 8 & & \multicolumn{4}{|c|}{$127.9 \mathrm{C}$} \\
\hline 9 & $7.38(\mathrm{~d}, 7.7)$ & \multicolumn{4}{|c|}{$130.4 \mathrm{CH}$} \\
\hline 10 & $7.66(\mathrm{~d}, 7.7)$ & \multicolumn{4}{|c|}{$125.9 \mathrm{CH}$} \\
\hline 11 & & \multicolumn{4}{|c|}{$132.7 \mathrm{C}$} \\
\hline 12 & & \multicolumn{4}{|c|}{$129.4 \mathrm{C}$} \\
\hline 13 & & \multicolumn{4}{|c|}{$166.1 \mathrm{C}$} \\
\hline
\end{tabular}

* All the amino acid residues are in the L- configuration except for Valine.

Table 4. One dimension NMR data of compound 4.

\begin{tabular}{|c|c|c|c|c|c|}
\hline Residue & $\begin{array}{c}\delta_{\mathrm{H}}\left(\mathrm{CDCl}_{3}, 400\right. \\
\mathrm{MHz} \text {, and } J \text { in } \mathrm{Hz})\end{array}$ & $\begin{array}{c}\delta_{C}\left(C D_{3} \text { OD and }\right. \\
100 \mathrm{MHz})\end{array}$ & Residue & $\begin{array}{c}\delta_{\mathrm{H}}\left(\mathrm{CD}_{3} \mathrm{OD}, 400\right. \\
\mathrm{MHz}, \text { and } J \text { in } \mathrm{Hz})\end{array}$ & $\begin{array}{c}\delta_{\mathrm{C}}\left(\mathrm{CDCl}_{3} \text { and }\right. \\
100 \mathrm{MHz})\end{array}$ \\
\hline \multirow{6}{*}{ Thr } & Ring A & & & Ring B & \\
\hline & $7.73 \mathrm{NH}(\mathrm{d}, 6.6)$ & - & Thr & $7.18 \mathrm{NH}(\mathrm{d}, 6.9)$ & - \\
\hline & $4.66(\mathrm{~m})$ & $54.9 \mathrm{CH}$ & & $4.55(\mathrm{~m})$ & $55.2 \mathrm{CH}$ \\
\hline & $5.23(\mathrm{~m})$ & $75.1 \mathrm{CH}$ & & $5.23(\mathrm{~m})$ & $75.1 \mathrm{CH}$ \\
\hline & $1.28(\mathrm{~m})$ & $17.8 \mathrm{CH} 3$ & & $1.29(\mathrm{~m})$ & $17.4 \mathrm{CH} 3$ \\
\hline & - & 168.9 & & - & 166.3 \\
\hline \multirow{6}{*}{$N-\mathrm{Me}$ Val } & $2.93(\mathrm{~s})$ & $39.2 \mathrm{~N}-\mathrm{Me}$ & $N$-Me Val & $2.95(N-\mathrm{Me})$ & $39.3 \mathrm{~N}-\mathrm{Me}$ \\
\hline & $2.7(\mathrm{~m})$ & $71.2 \mathrm{CH}$ & & $2.7(\mathrm{~m})$ & $71.4 \mathrm{CH}$ \\
\hline & $2.68(\mathrm{~m})$ & $26.90 \mathrm{CH}$ & & $2.68(\mathrm{~m})$ & $26.94 \mathrm{CH}$ \\
\hline & $0.75(\mathrm{~m})$ & $19.07 \mathrm{CH} 3$ & & $0.76(\mathrm{~m})$ & $19.11 \mathrm{CH} 3$ \\
\hline & $0.98(\mathrm{~m})$ & $21.6 \mathrm{CH} 3$ & & $0.99(\mathrm{~m})$ & $21.7 \mathrm{CH} 3$ \\
\hline & - & $168.5 \mathrm{C}$ & & & $166.2 \mathrm{C}$ \\
\hline \multirow[t]{3}{*}{ N-Me Gly } & $2.89(\mathrm{~s})$ & $34.9(N-\mathrm{Me})$ & N-Me Gly & $2.89(\mathrm{~s})$ & $35.0(N-\mathrm{Me})$ \\
\hline & $4.78,3.63(\mathrm{~m})$ & $51.4 \mathrm{CH} 2$ & & $4.77,3.65$ & $51.4 \mathrm{CH} 2$ \\
\hline & & $166.4 \mathrm{C}$ & & & $166.5 \mathrm{C}$ \\
\hline \multirow[t]{5}{*}{ Pro } & $6(d, 9.29)$ & $56.5 \mathrm{CH}$ & Pro & $6.07(d, 9.43)$ & $56.2 \mathrm{CH}$ \\
\hline & $2.11,2.30(\mathrm{~m})$ & $22.8 \mathrm{CH} 2$ & & $2.13,2.32$ & $23.1 \mathrm{CH} 2$ \\
\hline & $3.75,3.98(\mathrm{~m})$ & $47.3 \mathrm{CH} 2$ & & $3.75,3.86$ & $47.6 \mathrm{CH} 2$ \\
\hline & $1.85,2.71(\mathrm{~m})$ & $31.0 \mathrm{CH} 2$ & & $1.87,2.65$ & $31.2 \mathrm{CH} 2$ \\
\hline & & $173.2 \mathrm{C}$ & & & $173.3 \mathrm{C}$ \\
\hline
\end{tabular}


Table 4. Cont

\begin{tabular}{|c|c|c|c|c|c|}
\hline Residue & $\begin{array}{c}\delta_{\mathrm{H}}\left(\mathrm{CDCl}_{3}, 400\right. \\
\mathrm{MHz} \text {, and } J \text { in } \mathrm{Hz})\end{array}$ & $\begin{array}{c}\delta_{C}\left(C D_{3} \mathrm{OD} \text { and }\right. \\
100 \mathrm{MHz})\end{array}$ & Residue & $\begin{array}{c}\delta_{\mathrm{H}}\left(\mathrm{CD}_{3} \mathrm{OD}, 400\right. \\
\mathrm{MHz}, \text { and } J \text { in } \mathrm{Hz})\end{array}$ & $\begin{array}{c}\delta_{\mathrm{C}}\left(\mathrm{CDCl}_{3} \text { and }\right. \\
100 \mathrm{MHz})\end{array}$ \\
\hline \multirow[t]{7}{*}{ Isoleu } & $8.22 \mathrm{NH}(\mathrm{d}, 6.0)$ & - & Isoleu & $8.01 \mathrm{NH}(\mathrm{d}, 6.0)$ & - \\
\hline & $3.60(\mathrm{~m})$ & $58.4 \mathrm{CH}$ & & $3.63(\mathrm{~m})$ & $58.5 \mathrm{CH}$ \\
\hline & $1.96(\mathrm{~m})$ & $38.4 \mathrm{CH}$ & & $1.91(\mathrm{~m})$ & $38.8 \mathrm{CH}$ \\
\hline & $1.45,0.97$ & $25.01 \mathrm{CH} 2$ & & $1.46,0.96$ & $25.01 \mathrm{CH} 2$ \\
\hline & $1.11(\mathrm{~d}, 6.6)$ & $14.8 \mathrm{CH} 3$ & & $1.11(\mathrm{~d}, 6.6)$ & $14.9 \mathrm{CH} 3$ \\
\hline & 0.92 & $12.4 \mathrm{CH} 3$ & & $0.91 \mathrm{~m}$ & $12.4 \mathrm{CH} 3$ \\
\hline & - & $174.2 \mathrm{C}$ & & - & $173.7 \mathrm{C}$ \\
\hline \multicolumn{6}{|c|}{ Phenoxazinone } \\
\hline 1 & \multicolumn{5}{|c|}{$167.8 \mathrm{C}$} \\
\hline 2 & \multicolumn{5}{|c|}{$101.8 \mathrm{C}$} \\
\hline 3 & \multicolumn{5}{|c|}{$147.5 \mathrm{C}$} \\
\hline 4 & \multicolumn{5}{|c|}{$179.9 \mathrm{C}$} \\
\hline 5 & \multicolumn{5}{|c|}{$113.3 \mathrm{C}$} \\
\hline 6 & \multicolumn{5}{|c|}{$145.5 \mathrm{C}$} \\
\hline 7 & \multicolumn{5}{|c|}{$140.5 \mathrm{C}$} \\
\hline 8 & \multicolumn{5}{|c|}{$127.7 \mathrm{C}$} \\
\hline 9 & $7.38(\mathrm{~d}, 7.7)$ & \multicolumn{4}{|c|}{$130.4 \mathrm{CH}$} \\
\hline 10 & $7.66(\mathrm{~d}, 7.7)$ & \multicolumn{4}{|c|}{$125.9 \mathrm{CH}$} \\
\hline 11 & & \multicolumn{4}{|c|}{$132.7 \mathrm{C}$} \\
\hline 12 & & \multicolumn{4}{|c|}{$129.4 \mathrm{C}$} \\
\hline 13 & & \multicolumn{4}{|c|}{$167.6 \mathrm{C}$} \\
\hline
\end{tabular}

\section{Discussion}

In this study, fifty Actinobacteria were isolated from the Sinai desert in Egypt. Actinobacteria growth was recorded on mineral salt media, basal media, and starch casein media at 30 ${ }^{\circ} \mathrm{C}$ only rather than at $37^{\circ} \mathrm{C}$ and $45^{\circ} \mathrm{C}$. We conducted antimicrobial screening for 50 desert Actinobacteria isolated from Egyptian soil against some clinical multidrug-resistant S. aureus pathogens. Our results confirmed that 16 out of 50 Actinobacteria isolates (32\%) inhibited the growth of pathogenic multidrug-resistant $S$. aureus. Similar inhibition zone diameters of the DH7 crude extract and CN10 antibiotic were reported against $S$. aureus isolates No. 31 and No. 55. However, the active fraction produced by Streptomyces sp. DH7 showed a higher inhibition zone diameter against S. aureus (No. 31) than AZM15 antibiotic. This is an indication of the potency of bioactive compounds produced by Streptomyces sp. DH7.

Our results agree with the work of previous reports, declaring the potency of Actinobacteria isolated from Egyptian deserts. An Egyptian study reported that 10 isolates out of $75(0.13 \%$ of the active strains) showed inhibition to non-clinical S. aureus [25]. It is of interest to mention that our study is unique in showing the effect of desert Actinobacteria extracts on S. aureus isolates from clinical hospital samples. The results obtained in this study support the fact that nature is the infinite source of potent antibiotics $[12,15,25,26]$. It is of interest to mention that the phylogenetic analysis of the partial 16S rRNA gene sequencing of Streptomyces sp. DH7 showed a low bootstrap value with (78\%) Streptomyces flavofuscus strain NRRL B-2594, which reflects that Streptomyces sp. DH7 is diverse from already known species on the database and hence it has a distinct metabolic profile.

NMR data of compounds $\mathbf{1}$ and $\mathbf{2}$ indicate that (Table 3) compound $\mathbf{2}$ is an ethyl derivative of 1 . HSQC correlations confirmed single bond $\mathrm{H}-\mathrm{C}$ connections for compounds 1 and 2 . To the best of our knowledge, this is the first report for the isolation of compounds 1 and 2 from a natural source. Regarding compound 3,1D and 2D NMR (Table 3) spectra were in accordance with the literature data of the known cyclic peptide actinomycin $\mathrm{D}$ with the replacement of one valine residue with isoleucine residue (38). The 1D and 2D NMR data of compound 4 (Table 4) showed a similar pattern of compound 3; however, HMBC correlations revealed the correlation of isoleucine methylene carbon at $\delta c 25.14$ with four methyl protons instead of the two in compound 3. Moreover, the valine methine carbon at $\delta \mathrm{c} 31.8$ presented in compound $\mathbf{3}$, while it was not present in compound 4 . Additionally, the 
signal at 25.14 showed high intensity compared to its partner in compound 3, suggesting its correlation to two methylene carbons instead of one methylene. This result coupled with the mass spectrum suggests that compound 4 is an actinomycin D analog, with the replacement of the two valine residues in both rings with isoleucine residues. Compound 4 was isolated in a lower quantity than compound 3 as some of the carbons in compound 3 were not as clear in the APT spectrum, although they were detected from its HMBC traces. To the best of our knowledge, compounds 3 and 4 are new natural products not isolated before from a natural source, although they have been chemically synthesized [27].

Actinomycin D (AMD) is a peptide antibiotic secreted by Streptomyces melanochromogenes and Streptomyces parvullus consisting of a planar 2-aminophenoxazin-3-one chromophore and two large cyclic pentapeptide lactones [28]. It has been used in the treatment of extremely aggressive malignancies as an anticancer agent in clinical trials [29]. AMD is being used to treat high-risk cancers in conjunction with other anticancer medicines [30]. AMD binds non-covalently to DNA and strongly inhibits the transcription of DNA to RNA. Consequently, it became a strong tool in biochemistry, molecular, and cell biology research [31]. However, in our study, we reported that the Actinomycin analog is produced from Streptomyces sp. DH7. Our results agree with that in Zhang et al. in identifying actinomycin D analogs, including D-valine residues (the second amino acid residue in the cyclic depsipeptide of AMD) and the $N$-methyl-L-valine residues (the fifth amino acid residue in the cyclic depsipeptide of AMD). The authors switched them with D-Phe or L- and Dforms of $\mathrm{N}$-methylvalines, $\mathrm{N}$-methylisoleucine, $\mathrm{N}$-methylleucine, $\mathrm{N}$-methylphenylalanine, $\mathrm{N}$-methylalanine, and sarcosine [27]. However, the analogs identified in our study showed antimicrobial effects against MRSA, which was not previously reported for the actinomycin $\mathrm{D}$ analogs identified in the mentioned study [27]. Another study revealed that Streptomyces griseoruber NBRC 12,873 isolated from medicinal plants roots, namely actinomycin-D (actD), presented with inhibitory activity against various gram-positive and gram-negative bacterial cultures [32]. Another research group found that Streptomyces heliomycini isolated from the marine coast exhibited strong antibacterial activity against Staphylococcus aureus. Using MS and NMR techniques, the active compounds were identified as actinomycins $\mathrm{X} 0 \beta, \mathrm{X} 2$, and D [33]. In 2019, a similar report declared the production of actinomycin $\mathrm{D}$ by a genus Streptomyces isolated from the Saharan desert [34]. Literature ensures that Actinobacteria in different environments produce Actinomycin D, although in our study, we identified Actinomycin analogs with a high inhibitory effect against MRSA strains produced by desert Actinobacteria. In 2018, endophytic actinomycetes isolated from the macro fungus Ganoderma applanatum were reported to produce 2-methyl-actinomycin D analog, which has better anti-tumor activity than Actinomycin D. Another study declared the identification of novel methylated actinomycin D (mAct D) [35].

Our findings strongly suggest the production of cyclic peptide actinomycin D and actinomycin analogs as produced by desert Actinobacteria isolated from the Sinai Peninsula, Egypt. To the best of our knowledge, this is the first report declaring the production of actinomycin analogs inhibiting clinical multidrug-resistant $S$. aureus samples from Egyptian desert Actinobacteria. Future studies involving large-scale fermentations and purifications of Streptomyces sp. DH7 will be conducted to categorize the properties of these new analogs. For instance, it may prove better antibacterial effects than that of already identified similar ones. These conclusions would overwhelm the resistance mechanisms in the pathogenic bacteria in this area. Our findings will have a positive effect on health research areas and will aid in finding natural solutions to repair fragile ecosystems on both a human and global scale. 


\section{Materials and Methods}

\subsection{Sample Collection}

In 2018, five samples were collected from the Sinai desert at Saint Catherine City, south of the Sinai Governorate, Egypt, at GPS coordinates $28^{\circ} 33^{\prime} 42.88^{\prime \prime} \mathrm{N} 33^{\circ} 56^{\prime} 57.62^{\prime \prime} \mathrm{E}$ (Figure 9). Each sample was taken from the desert at $5 \mathrm{~cm}$ depth in clean plastic bags. Samples were stored in sterile containers in the refrigerator at $4{ }^{\circ} \mathrm{C}$ for further analysis.



Figure 9. Geography of sampling sites for Actinobacteria isolation from the Sinai desert, south of the Sinai Governorate, Egypt (red spot). This map is retrieved from the satellite map of Egypt (https://www.google.com/maps/. Accessed on: 1 January 2021).

\subsection{Isolation of Actinobacteria from Sinai Desert Soil}

Five soil samples were subjected to the serial dilution method. An aliquot of $0.1 \mathrm{~mL}$ inoculum of $10^{-3}$ and $10^{-4}$ dilution was cultured on mineral salt media, basal media, and starch casein media for 14 days at $30^{\circ} \mathrm{C}, 37^{\circ} \mathrm{C}$, and $45^{\circ} \mathrm{C}$. Then, colonies were selectively picked and purified on starch casein agar plates for further analysis.

\subsection{Agar Well Diffusion Method}

A preliminary screening of Actinobacteria extracts was conducted against 9 multidrugresistant $S$. aureus strains from a national hospital in Cairo, Egypt, which were previously identified using MALDI (matrix-assisted laser desorption ionization/time-of-flight), and MIC were recorded against several antibiotics (Tables S1 and S2). Antimicrobial activity was evaluated using the agar well diffusion method [36]. Actinobacteria extracts were performed using a loopful of Actinobacteria spores inoculated to $35 \mathrm{~mL}$ of starch casein broth media. Flasks were incubated for 7 days at $30{ }^{\circ} \mathrm{C}$ in a shaking incubator. Cell-free supernatant of Actinobacteria $(250 \mu \mathrm{L})$ was added in each well in nutrient agar Petri dishes containing 0.5 Mcfarland of MRSA-tested bacterial spores [37]. Petri dishes were then incubated for $24 \mathrm{~h}$ at $37^{\circ} \mathrm{C}$ and the inhibition zone areas were recorded [38]. Two antibiotics, namely Gentamicin (CN10) and Azithromycin (AZM15), were used as a control in this experiment. All tests and experiments were made in duplicates. Tested MRSA bacteria were cultivated overnight in nutrient broth at $37^{\circ} \mathrm{C}$ before the test. A control multidrug-sensitive Staphylococcus aureus ATCC 6538 strain was obtained from the Microbial Resources Center (MIRCEN) at the Faculty of Agriculture, Ain Shams University, Cairo, Egypt.

\subsection{Microscopic Analysis of Isolate DH7}

Microscopic characterization of the Actinobacteria isolate was examined according to Bergey's Manual of Systematic Bacteriology, Vol. 4 [39]. Morphological characteristics including aerial and substrate mycelium as well as exopigment production were examined by eyes alone after 8 days of culturing isolate DH7 [40]. The potent Actinobacteria isolate 
DH7 was subjected to further study using a scanning electron microscope. Isolate DH7 was inoculated on starch casein agar and incubated for 7 days, after which a block was then cut from the agar plate and fixed in $2 \%$ glutaraldehyde vapor at $37{ }^{\circ} \mathrm{C}$ for $3 \mathrm{~h}$. The dehydration step was conducted using a series of ethanol solutions $(50,60,70,80$, and 95\%, 15 min each; 2 times with 100\% ethanol, $30 \mathrm{~min} /$ time). Ethanol was replaced with acetone, which was subjected to a critical-point dryer, and then coated with gold using a Gold Sputter. Examination by scanning electron microscopy at the Regional Center for Mycology and Biotechnology (RCMB), Al Azhar University, Egypt, was conducted [41].

\subsection{Extraction of Genomic DNA from Actinobacteria Isolate DH7}

DNA extraction was conducted using the GeneJet genomic DNA purification Kit (Thermo K0721). DH7 was inoculated in $35 \mathrm{~mL}$ of starch casein broth for 7 days in a shaking incubator at $30{ }^{\circ} \mathrm{C}$. Cells were harvested up to $2 \times 10^{9}$ bacterial cells in a $2 \mathrm{~mL}$ microcentrifuge tube, were centrifuged for $10 \mathrm{~min}$ at $5000 \times g$, and then the supernatant was discarded. The pellet was resuspended in $180 \mu \mathrm{L}$ of Digestion Solution and an aliquot of $20 \mu \mathrm{L}$ Proteinase K Solution was added. The sample was mixed and incubated at $56^{\circ} \mathrm{C}$ for $30 \mathrm{~min}$. An amount of $20 \mu \mathrm{L}$ of RNase A solution was added to the cells, mixed, and incubated for $10 \mathrm{~min}$ at $37^{\circ} \mathrm{C}$. An aliquot of $200 \mu \mathrm{L}$ Lysis Solution was added to the sample and mixed for about $15 \mathrm{~s}$. An amount of $400 \mu \mathrm{L}$ of $50 \%$ ethanol was added and mixed by pipetting. The lysate was transferred to a GeneJET ${ }^{\mathrm{TM}}$ Genomic DNA Purification Column which was placed in a collection tube and centrifuged for $1 \mathrm{~min}$ at $6000 \times g$. The GeneJET ${ }^{\mathrm{TM}}$ DNA purification column was inserted into a clean $2 \mathrm{~mL}$ collection tube and $500 \mu \mathrm{L}$ of Wash Buffer was added to the sample, followed by centrifugation for $1 \mathrm{~min}$ at $8000 \times g$. The flow-through was discarded and the purification column was inserted again into the collection tube, followed by the addition of $500 \mu \mathrm{L}$ of Wash Buffer II to the GeneJET ${ }^{\mathrm{TM}}$ DNA purification column. It was centrifuged for $3 \mathrm{~min}$ at $12,000 \times g$. The collection tube containing the flow-through solution was discarded and the DNA GeneJET ${ }^{\mathrm{TM}}$ purification column was transferred to a sterile $1.5 \mathrm{~mL}$ microcentrifuge tube. Finally, an aliquot of $80 \mu \mathrm{L}$ of Elution Buffer was added to the center of the GeneJET ${ }^{\mathrm{TM}}$ DNA purification column to elute the genomic DNA. Further incubation for $2 \mathrm{~min}$ at room temperature and centrifugation for $1 \mathrm{~min}$ at $8000 \times g$ was performed. The purification column was discarded and the purified DNA concentration was verified using a Nanodrop spectrophotometer (ND-2. 1000, Nanodrop Technologies, Wilmington, DE, USA), after which it was stored at $-20{ }^{\circ} \mathrm{C}$.

\subsection{Polymerase Chain Reaction of $16 S-r R N A$ Genes}

The extracted DNA was subjected to PCR analysis of the 16S rRNA gene as described by [42]. Universal bacterial 16S rDNA used included the forward primer (A GTT TGA TCC TGG CTC AG) and reverse primer (GGT TAC CTT GTT ACG ACT T). PCR reaction was performed as follows: $25 \mu \mathrm{L}$ of the Maxima ${ }^{\circledR}$ Hot Start PCR Master Mix; $1 \mu \mathrm{L}$ of $20 \mu \mathrm{M}$ 16SrRNA forward primer; $1 \mu \mathrm{L}$ of $20 \mu \mathrm{M}$ 16SrRNA reverse primer; $5 \mu \mathrm{L}$ of template DNA; and $18 \mu \mathrm{L}$ nuclease-free water. Amplification was conducted using a thermal cycler (Applied biosystem 337) with initial denaturation at $94{ }^{\circ} \mathrm{C}$ for $10 \mathrm{~min}$ and then 35 cycles of $30 \mathrm{~s}$ at $95^{\circ} \mathrm{C}, 1 \mathrm{~min}$ at $65^{\circ} \mathrm{C}, 1.30 \mathrm{~min}$ at $72{ }^{\circ} \mathrm{C}$, and finally $10 \mathrm{~min}$ at $72{ }^{\circ} \mathrm{C}$. The negative control contained all components of the mixture, except the DNA template.

\subsection{Agar Electrophoresis and PCR Product Purification}

PCR products were subjected to gel electrophoresis. One gram of agarose gel was dissolved in $100 \mathrm{~mL}$ of TAE buffer and $15 \mu \mathrm{L}$ of ethidium bromide solution $(10 \mathrm{mg} / \mathrm{mL}$ Sigma). Agarose gel was poured into the gel casting tray and combs were added. It was cooled until the agarose was solidified. Gel combs were taken off to produce wells for loading. An aliquot of $8 \mu \mathrm{L}$ of the PCR product was loaded into the wells. A DNA marker (100 bp plus, Vivantis) was loaded into the first well to check the size of the amplified DNA. The gel electrophoresis apparatus was adjusted at $130 \mathrm{~V}$ for $40 \mathrm{~min}$. DNA bands were 
visualized using a gel documentation system (Syngene-Ingenius3). The DNA bands with a size of $500 \mathrm{bp}$ indicated the precise amplification.

The PCR product was cleaned using the GeneJET ${ }^{\mathrm{TM}}$ PCR Purification Kit (Thermo K0701). An amount of $45 \mu \mathrm{L}$ of Binding Buffer was transferred to the PCR mixture and mixed carefully. The mixture was transferred to the GeneJET ${ }^{\mathrm{TM}}$ purification column, centrifuged for $30 \mathrm{~s}$ at $12,000 \times g$, and the flow-through was discarded. Further addition of $100 \mu \mathrm{L}$ of wash buffer to the GeneJET ${ }^{\mathrm{TM}}$ purification column and centrifugation for $30 \mathrm{~s}$ at $12,000 \times g$ were performed. The flow-through was discarded and the purification column was added back into the collection tube. Centrifugation of the empty GeneJET ${ }^{\mathrm{TM}}$ purification column was performed for an extra $1 \mathrm{~min}$. The GeneJET ${ }^{\mathrm{TM}}$ purification column was added to a clean $1.5 \mathrm{~mL}$ microcentrifuge tube with $25 \mu \mathrm{L}$ of Elution Buffer, followed by centrifugation for $1 \mathrm{~min}$. The GeneJET ${ }^{\mathrm{TM}}$ purification column was then discarded and the purified PCR product was stored at $-20^{\circ} \mathrm{C}$.

\subsection{S rDNA Sequencing and Phylogenetic Analysis}

The PCR product was subjected to Sanger sequencing technology using the ABI 3730xl DNA sequencer at GATC Company, Germany. The $16 \mathrm{~S}$ rDNA sequences were deposited at the GenBank database (http://blast.ncbi.nlm.nih.gov/, accessed on 1 January 2021) to show the neighboring matches of known species to the 16S rDNA sequence of isolate DH7. Phylogenetic analysis was processed using the CLUSTAL W program [43] and a neighbor-joining phylogenetic tree was constructed using Molecular Evolutionary Genetics Analysis (MEGA) software version 6 [44].

\subsection{Determination of Minimum Inhibitory Concentrations of the Active Fraction of Streptomyces sp. DH7}

The minimum inhibitory concentration (MIC) of the active fraction (an intermediate stage of the purification procedure) was investigated via micro broth assay [36]. A stock solution of the active fraction dissolved in an equal amount of DMSO and was used to prepare different concentrations $(0.5,1,2,4,8,16,32,64,128$, and $256 \mu \mathrm{g} / \mu \mathrm{L})$. An aliquot of $5 \mu \mathrm{L}$ from an overnight culture of $S$. aureus ATCC 6538 ( $0.5 \mathrm{Mcfarland}$ ) was added to each well of a sterile 96-well microtiter plate containing the test concentrations of the active fraction. The final volume in each well was $100 \mu \mathrm{L}$ and each sample was prepared in duplicates. Growth control (bacterial suspension only) and background control (media only) were included in the microtiter plate. The plate was incubated in a static incubator for $24 \mathrm{~h}$ at $37^{\circ} \mathrm{C}$. Then, optical densities were recorded using a multi-detection microplate reader (Bio-Tek-Synergy HT Microplate Reader, BioTek Instruments, Winooski, VT, USA) at $600 \mathrm{~nm}$. Further confirmation of MIC was also estimated by transferring $10 \mu \mathrm{L}$ of the mixture to nutrient agar plates. Plates were then incubated in the static incubator for $24 \mathrm{~h}$ at $37^{\circ} \mathrm{C}$. The viability of the bacteria was detected at this stage by an unaided eye. Lack of bacterial growth on the plates implied that only non-viable organisms were present. The kill-growth curve, which shows changes in the optical density of bacterial growth against active fraction concentrations, was plotted using Origin Pro8 for data analysis and graphing (https:/ / www.originlab.com/. Accesed on: 1 December 2020). The MIC is well defined as the lowest concentration of the antimicrobial agent that inhibits visible growth of the tested isolate in nutrient broth was observed with an unassisted eye [36]. Additionally, it is also defined from a spectrophotometric view as the concentration at which there is a sharp decline in the absorbance value.

\subsection{Determination of the Minimum Bactericidal Concentrations of the Active Fraction of Streptomyces sp. DH7}

Minimum bactericidal concentrations (MBC) are defined as the lowest broth dilution of antimicrobials that prevents the growth of the organism on the agar plate [45]. Viability of bacteria in wells of no growth in previously prepared 96-well microtiter plate was checked by transferring $5 \mu \mathrm{L}$ of the mixture to nutrient agar plates. Then, plates were incubated in a static incubator for $24 \mathrm{~h}$ at $37^{\circ} \mathrm{C}$. The bacteria growth survival was detected 
at this stage using an unassisted eye. No growth indicated the MBC of the active fraction against $S$. aureus ATCC 6538.

\subsection{Fractionation of Streptomyces sp. DH7 Extract and Bioassay of the Identified Compounds}

Spore suspensions of Streptomyces sp. DH7 were added to $1500 \mathrm{~mL}$ soya bean meal broth media at a ratio of $1 \% v / v$ and were incubated for 8 days at $30^{\circ} \mathrm{C}(150 \mathrm{RPM})$. The cell-free supernatant was filtered and tested against $S$. aureus via the agar well diffusion method as previously stated. Bioactive components were extracted from the cell-free supernatant three times using ethyl acetate $(1: 1 v / v)$ in a separating funnel and the ethyl acetate wells were used as the control. The ethyl acetate extract of the fermentation broth was evaporated and the residue was then defatted by partitioning using $n$-hexane and $90 \%$ aqueous methanol.

\subsection{Purification and Identification of Bioactive Fractions of Streptomyces sp. DH7}

The $90 \%$ methanolic fraction (600 mg) was applied on vacuum liquid chromatography (VLC) assembly packed with normal-phase silica gel 60 and was eluted using n-hexane (ethyl acetate gradient, from $100 \%$ to $0 \%$ ) followed by dichloromethane (methanol, from $100 \%$ to $0 \%$ ). Then, the fractions were collected, analyzed using TLC with different mobile phases, and similar fractions were pooled together to finally yield 5 major fractions (F1-5).

Fraction 3 eluted with 50\% EtOAc in n-hexane (130 mg) was further purified using Sephadex LH-20 eluted with DCM:MeOH (1:1) to yield two major sub-fractions. Subfraction 2 (90 $\mathrm{mg}$ ) yielded a reddish residue and was further analyzed by LC/ESI/MS to reveal a group of peptides. This fraction was further purified using semi-preparative HPLC with $70 \%$ Acetonitirile in water as the mobile phase to yield compound 3 (10 mg) and 4 (5 mg).

Similarly pooled fraction 4 eluted with $80 \%$ DCM in $\mathrm{MeOH}(80 \mathrm{mg})$ was purified using Sephadex LH-20 eluted with $\mathrm{MeOH}$, yielding three sub-fractions. Sub-fraction 3 (40 mg), showing two major spots on TLC, was purified using semi-preparative HPLC with $40 \%$ Acetonitirile in water as the mobile phase to yield two pure compounds, namely compound 1 ( $2 \mathrm{mg}$ ) and compound 2 (3 mg).

Normal-phase column chromatography was performed using silica gel 60 (0.04-0.063, Merck, Darmstadt, Germany) on VLC assembly that was equipped with a vacuubrand ${ }^{\circledR}$ (Germany) vacuum pump. TLC analysis was performed using normal-phase silica gel pre-coated plates F254 (Merck, Germany). Size exclusion chromatography was performed using Sephadex LH-20 (Sigma Aldrich, Taufkirchen, Germany).

UPLC/ESI/MS was performed using Shimadzu LCMS 8045, utilizing the UPLC shimpack RP-C18 column (particle size: $3 \mathrm{~mm} \times 70 \mathrm{~mm}, 2.7 \mu \mathrm{m}$ ) using isocratic elution with $80 \%$ acetonitrile in $0.1 \%$ formic acid (all solvents are mass grade Sigma Aldrich). Final purification steps were conducted using Shimadzu-LC-20AP preparative HPLC equipped with PDA and the kromasil RP-C18 column $(10 \mathrm{~mm} \times 250 \mathrm{~mm}, 5 \mu \mathrm{m}$ particle size $)$ detection was done on $235 \mathrm{~nm}, 254 \mathrm{~nm}$ and $280 \mathrm{~nm}$. NMR spectra were recorded using Bruker Avance HD III $400 \mathrm{MHz}$ (switzerland); pure compounds were dissolved in $0.6 \mathrm{~mL}$ of deuterated solvents (Sigma Aldrich) and were placed in $5 \mathrm{~mm}$ NMR tubes; and proton NMR spectra were recorded at $400 \mathrm{MHz}$ and $13 \mathrm{C} \mathrm{NMR}$ at $100 \mathrm{MHz}$ at the Center of Drug Discovery Research and Development, Department of Pharmacognosy, Faculty of Pharmacy, Ain Shams University, Egypt.

\subsection{Bioassay of the Active Compounds of Streptomyces sp. DH7}

The antimicrobial activity against MRSA strains of the four purified compounds was tested as follows: each purified compound was dissolved in DMSO at a concentration of $1 \mu \mathrm{g} / \mu \mathrm{L}$. Then, a volume of $20 \mu \mathrm{L}$ of both compound 3 and 4 was added to sterile filter paper discs and a control disc containing DMSO was also prepared. Using sterile forceps, each disc was added on nutrient agar Petri dishes containing 0.5 Mcfarland of fresh MRSA-tested bacterial cells. Additionally, the agar well diffusion method was performed 
to record the inhibitory effect for some samples. Petri dishes were then incubated for $24 \mathrm{~h}$ at $37^{\circ} \mathrm{C}$ and the inhibition zone areas were recorded. All tests were performed in duplicates.

\section{Conclusions}

This study reported the potency of desert Actinobacteria isolated from the Sinai desert against clinical multidrug-resistant $S$. aureus strains. We still believe that listening to nature and learning how to communicate with the environment will provide us with biologically safe opportunities to improve human health. This study shows great promise not only for Egypt but also on the global scale. This study highlights actinomycin D analogs isolated from desert Actinobacteria as suitable candidates for the treatment of infections caused by multidrug-resistant $S$. aureus pathogens. We suggest that current large-scale fermentations and purifications be performed to further explore the properties of these antimicrobials. We ensure that this study will have a positive impact on human health and social welfare. It will support the medical, pharmaceutical, and public health sectors in Egypt and worldwide.

Supplementary Materials: The following are available online at https:/ /www.mdpi.com/article/10 .3390 /antibiotics10101264/s1, Figure S1: 1H NMR spectrum of compound 1; Figure S2: APT NMR spectrum of compound 1; Figure S3: COSY NMR spectrum of compound 1; Figure S4: HSQC NMR spectrum of compound 1; Figure S5: HMBC NMR spectrum of compound 1; Figure S6: 1H NMR spectrum of compound 2; Figure S7: APT NMR spectrum of compound 2; Figure S8: COSY NMR spectrum of compound 2; Figure S9: HSQC NMR spectrum of compound 2; Figure S10: HMBC NMR spectrum of compound 2; Figure S11: 1H NMR spectrum of compound 3; Figure S12: APT NMR spectrum of compound 3; Figure S13: COSY NMR spectrum of compound 3; Figure S14: HSQC NMR spectrum of compound 3; Figure S15: HMBC NMR spectrum of compound 3; Figure S16: TOCSY NMR spectrum of compound 3; Figure S17: 1H NMR spectrum of compound 4; Figure S18: APT NMR spectrum of compound 4; Figure S19: COSY NMR spectrum of compound 4; Figure S20: HSQC NMR spectrum of compound 4; Figure S21: HMBC NMR spectrum of compound 4; Figure S22: TOCSY NMR spectrum of compound 4; Table S1: Identification of bacterial strains using MALDI/TOF (matrix-assisted laser desorption ionization/time-of-flight), showing score values; and Table S2: Antimicrobial susceptibility profile of Staphylococcus aureus strains used in this study.

Author Contributions: D.H.A., conceptualization; H.A.E.S., investigation; A.M.E., visualization; D.H.A., H.A.E.S. and A.M.E., methodology; D.H.A., A.M.E. and D.E.E.-G., writing-original draft preparation; H.A.E.S. and A.M.E., writing-review and editing; A.N.B.S. and A.M.E., supervision; D.E.E.-G. and A.N.B.S., funding acquisition, resources, and validation; A.M.E., identification of the natural product. All authors have read and agreed to the published version of the manuscript.

Funding: A.N.B.S. and A.M.E. would like to acknowledge the Egyptian Science and Technology Develop ment Fund (STDF) for its financial support through grant number 5251 entitled "Center of Drug Discovery Research and Development".

Institutional Review Board Statement: Not applicable.

Informed Consent Statement: Not applicable.

Data Availability Statement: All data generated or analyzed for this study are included in the published article and supplementary materials are available.

Conflicts of Interest: The authors declare that the research was conducted in the absence of any commercial or financial relationships that could be construed as potential conflicts of interest.

\section{References}

1. Mathew, P.; Jaguga, C.; Mpundu, M.; Chandy, S.J. Building knowledge and evidence base on antimicrobial resistance in Africa, through 'One Health' based surveillance. Clin. Epidemiol. Glob. Health 2020, 8, 1313-1317. [CrossRef]

2. Sánchez, M.; Prim, N.; Rández-Gil, F.; Pastor, F.; Diaz, P. Engineering of baker's yeasts, E. coli and Bacillus hosts for the production of Bacillus subtilis lipase A. Biotechnol. Bioeng. 2002, 78, 3339-3345. [CrossRef] [PubMed]

3. O'neill, J. Review on Antimicrobial Resistance: Tackling a Crisis for the Health and Wealth of Nations; HM Government: London, UK, 2014. 
4. Monaco, M.; de Araujo, F.P.; Cruciani, M.; Coccia, E.M.; Pantosti, A. Worldwide epidemiology and antibiotic resistance of Staphylococcus aureus. In Staphylococcus Aureus; Springer: Berlin/Heidelberg, Germany, 2016; pp. 21-56.

5. Hassoun, A.; Linden, P.K.; Friedman, B. Incidence, prevalence, and management of MRSA bacteremia across patient populationsa review of recent developments in MRSA management and treatment. Crit. Care 2017, 21, 1211. [CrossRef] [PubMed]

6. Tong, S.Y.; Davis, J.S.; Eichenberger, E.; Holland, T.L.; Fowler, V.G. Staphylococcus aureus infections: Epidemiology, pathophysiology, clinical manifestations, and management. Clin. Microbiol. Rev. 2015, 28, 3603-3661. [CrossRef]

7. Weiner, L.M.; Webb, A.K.; Limbago, B.; Dudeck, M.A.; Patel, J.; Kallen, A.J.; Edwards, J.R.; Sievert, D.M. Antimicrobial-resistant pathogens associated with healthcare-associated infections: Summary of data reported to the National Healthcare Safety Network at the Centers for Disease Control and Prevention, 2011-2014. Infect. Control Hosp. Epidemiol. 2016, 37, 111288-111301. [CrossRef]

8. Lowy, F.D. Antimicrobial resistance: The example of Staphylococcus aureus. J. Clin. Investig. 2003, 111, 91265-91273. [CrossRef]

9. Hassan, A.M.; Ibrahim, O.; El Guinaidy, M. Surveillance of antibiotic use and resistance in orthopaedic department in an Egyptian university hospital. Int. J. Infect. Control 2010, 7. [CrossRef]

10. Stacey, H.J.; Clements, C.S.; Welburn, S.C.; Jones, J.D. The prevalence of methicillin-resistant Staphylococcus aureus among diabetic patients: A meta-analysis. Acta Diabetol. 2019, 56, 8907-8921. [CrossRef]

11. Amin, D.H.; Abdallah, N.A.; Abolmaaty, A.; Tolba, S.; Wellington, E.M.H. Microbiological and molecular insights on rare Actinobacteria harboring bioactive prospective. Bull. Natl. Res. Cent. 2020, 44, 15. [CrossRef]

12. Amin, D.H.; Abolmaaty, A.; Tolba, S.; Abdallah, N.A.; Wellington, E.M. Phylogenic Characteristics of a Unique Antagonistic Micromonospora Sp. Rc5 to S. aureus Isolated from Sinai Desert of Egypt. Curr. Res. Microbiol. Biotechnol. 2017, 5, 61295-61306. [CrossRef]

13. Amin, D.H.; Borsetto, C.; Abolmaaty, A.; Tolba, S.; Abdallah, N.A.; Wellington, E.M. Draft Genome Sequence of antagonistic Streptomyces sp. Ru87 Isolated from Egyptian Soil. J. Med. Sci. Clin. Res. 2017, 5, 30219-30221. [CrossRef]

14. Kämpfer, P. The family Streptomycetaceae, part I: Taxonomy. Prokaryotes 2006, 3, 538-604.

15. Amin, D.H.; Tolba, S.; Abolmaaty, A.; Abdallah, N.A.; Wellington, E.M. Phylogenetic and Antimicrobial Characteristics of a Novel Streptomyces sp. Ru87 Isolated from Egyptian Soil. Int. J. Curr. Microbiol. Appl. Sci. 2017, 6, 82524-82541. [CrossRef]

16. Cortés-Albayay, C.; Silber, J.; Imhoff, J.F.; Asenjo, J.A.; Andrews, B.; Nouioui, I.; Dorador, C. The polyextreme ecosystem, Salar de Huasco at the Chilean Altiplano of the Atacama Desert houses diverse Streptomyces spp. with promising pharmaceutical potentials. Diversity 2019, 11, 69. [CrossRef]

17. Heuer, H.; Krsek, M.; Baker, P.; Smalla, K.; Wellington, E. Analysis of actinomycete communities by specific amplification of genes encoding 16S rRNA and gel-electrophoretic separation in denaturing gradients. Appl. Environ. Microbiol. 1997, 63, 83233-83241. [CrossRef]

18. Monciardini, P.; Sosio, M.; Cavaletti, L.; Chiocchini, C.; Donadio, S. New PCR primers for the selective amplification of 16S rDNA from different groups of actinomycetes. FEMS Microbiol. Ecol. 2002, 42, 3419-3429. [CrossRef]

19. Neilson, J.W.; Quade, J.; Ortiz, M.; Nelson, W.M.; Legatzki, A.; Tian, F.; LaComb, M.; Betancourt, J.L.; Wing, R.A.; Soderlund, C.A. Life at the hyperarid margin: Novel bacterial diversity in arid soils of the Atacama Desert, Chile. Extremophiles 2012, 16, 3553-3566. [CrossRef]

20. Mansour, S.R. The occurrence and distribution of soil actinomycetes in Saint Catherine area, South Sinai, Egypt. Pak. Biol. Sci. 2003, 6, 7721-7728.

21. Bull, A. Extremophiles Handbook; Springer International Publishing: Cham, Switzerland, 2011.

22. McGinnies, W.G.; Goldman, B.J.; Paylore, P. Deserts of the World: An Appraisal of Research into Their Physical and Biological Environments; University of Arizona Press: Tucson, AZ, USA, 1968.

23. Danin, A. Desert Vegetation of Israel and Sinai; Cana Publishing House: Totnes, Devon, UK, 1983.

24. Phan, C.; Matsuda, K.; Balloo, N.; Fujita, K.; Wakimoto, T.; Okino, T. Argicyclamides A-C Unveil Enzymatic Basis for Guanidine Bis-prenylation. J. Am. Chem. Soc. 2021, 143, 10083-10087. [CrossRef]

25. Hozzein, W.N.; Rabie, W.; Ali, M.I.A. Screening the Egyptian desert actinomycetes as candidates for new antimicrobial compounds and identification of a new desert Streptomyces strain. Afr. J. Biotechnol. 2011, 10, 122295-1222301.

26. Lacret, R.; Oves-Costales, D.; Gómez, C.; Díaz, C.; de la Cruz, M.; Pérez-Victoria, I.; Vicente, F.; Genilloud, O.; Reyes, F. New ikarugamycin derivatives with antifungal and antibacterial properties from Streptomyces zhaozhouensis. Mar. Drugs 2015, 13, 1128-1140. [CrossRef]

27. Zhang, B.-Z.; Wang, K.-R.; Yan, J.-X.; Zhang, W.; Song, J.-J.; Ni, J.-M.; Wang, R. In Vitro and In Vivo antitumor effects of novel actinomycin D analogs with amino acid substituted in the cyclic depsipeptides. Peptides 2010, 31, 4568-4573. [CrossRef]

28. Farber, S. Chemotherapy in the treatment of leukemia and Wilms' tumor. JAMA 1966, 198, 8826-8836. [CrossRef]

29. Lewis, J.L., Jr. Chemotherapy of gestational choriocarcinoma. Obstet. Gynecol. Surv. 1973, 28, 7478-7480. [CrossRef]

30. Marina, N.; Fontanesi, J.; Kun, L.; Rao, B.; Jenkins, J.J.; Thompson, E.I.; Etcubanas, E. Treatment of childhood germ cell tumors: Review of the St. Jude experience from 1979 to 1988. Cancer 1992, 70, 102568-102575. [CrossRef]

31. Takusagawa, F.; Wen, L.; Chu, W.; Li, Q.; Takusagawa, K.T.; Carlson, R.G.; Weaver, R.F. Physical and biological characteristics of the antitumor drug actinomycin D analogues derivatized at N-methyl-L-valine residues. Biochemistry 1996, 35, 4013240-4013249. [CrossRef]

32. Praveen, V.; Tripathi, C. Studies on the production of actinomycin-D by Streptomyces griseoruber-A novel source. Lett. Appl. Microbiol. 2009, 49, 4450-4455. [CrossRef] 
33. Wang, D.; Wang, C.; Gui, P.; Liu, H.; Khalaf, S.M.H.; Elsayed, E.A.; Wadaan, M.A.M.; Hozzein, W.N.; Zhu, W. Identification, Bioactivity, and Productivity of Actinomycins from the Marine-Derived Streptomyces heliomycini. Front. Microbiol. 2017, 8, 1147. [CrossRef] [PubMed]

34. Djinni, I.; Defant, A.; Djoudi, W.; Chaouch, F.C.; Souagui, S.; Kecha, M.; Mancini, I. Modeling improved production of the chemotherapeutic polypeptide actinomycin D by a novel Streptomyces sp. strain from a Saharan soil. Heliyon 2019,5 , e01695. [CrossRef] [PubMed]

35. Li, C.-G.; Yuan, B.; Dong, M.-M.; Zhou, P.-Y.; Hao, Y.-X.; Sun, Y.-Y.; Xu, M.-K.; Li, D.; Kai, G.-Y.; Jiang, J.-H. Purification and identification of an actinomycin $\mathrm{D}$ analogue from actinomycetes associated with Ganoderma applanatum via magnetic molecularly imprinted polymers and tandem mass spectrometry. Food Chem. Toxicol. 2018, 119, 150-160. [CrossRef] [PubMed]

36. Clinical and Laboratory Standards Institute. Development of In Vitro Susceptibility Testing Criteria and Quality Control. Parameters; National Committee for Clinical Laboratory Standards: Annapolis Junction, MD, USA, 1987.

37. McFarland, J. The nephelometer: An instrument for estimating the number of bacteria in suspensions used for calculating the opsonic index and for vaccines. J. Am. Med. Assoc. 1907, 49, 141176-141178.

38. Cooper, K. The theory of antibiotic diffusion zones. In Analytical Microbiology II; Academic Press, Inc.: London, UK, 1972; pp. 13-30.

39. Locci, R. Streptomycetes and related genera. Bergey's Man. Syst. Bacteriol. 1989, 4, 2451-2504.

40. Shirling, E.T.; Gottlieb, D. Methods for characterization of Streptomyces species. Int. J. Syst. Bacteriol. 1966, 16, 3313-3340. [CrossRef]

41. Kaláb, M.; Yang, A.-F.; Chabot, D. Conventional scanning electron microscopy of bacteria. Infocus Mag. 2008, 10, 42-61. [CrossRef]

42. Hopwood, D.; Bill, M.; Charter, K.; Kieser, T.; Bruton, C.; Kieser, H.; Lydiate, D.; Smith, C.; Ward, J.; Schrempf, H. Genetic Manipulation of Streptomycetes: A Laboratory Manual; Cambridge University Press: Cambridge, UK, 1985.

43. Thompson, J.D.; Higgins, D.G.; Gibson, T.J. CLUSTAL W: Improving the sensitivity of progressive multiple sequence alignment through sequence weighting, position-specific gap penalties and weight matrix choice. Nucleic Acids Res. 1994, 22, 224673-224680. [CrossRef]

44. Tamura, K.; Stecher, G.; Peterson, D.; Filipski, A.; Kumar, S. MEGA6: Molecular evolutionary genetics analysis version 6.0. Mol. Biol. Evol. 2013, 30, 122725-122729. [CrossRef]

45. Amyes, S.; Miles, R.S.; Thomson, C.J.; Tillotson, G. Antimicrobial Chemotherapy: Pocketbook; CRC Press: Boca Raton, FL, USA, 1996. 